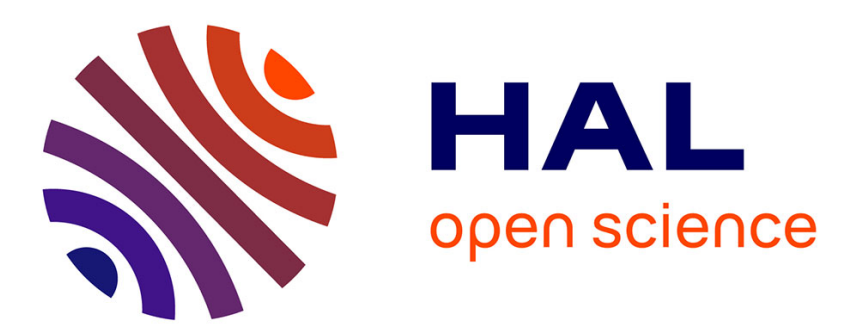

\title{
Romans Shape Today's Vegetation and Soils: Two Millennia of Land-Use Legacy Dynamics in Mediterranean Grasslands
}

\author{
Arne Saatkamp, Frédéric Henry, Thierry Dutoit
}

\section{To cite this version:}

Arne Saatkamp, Frédéric Henry, Thierry Dutoit. Romans Shape Today's Vegetation and Soils: Two Millennia of Land-Use Legacy Dynamics in Mediterranean Grasslands. Ecosystems, 2021, 24, pp.12681280. 10.1007/s10021-020-00581-w . hal-03000749

\section{HAL Id: hal-03000749 \\ https://hal.science/hal-03000749}

Submitted on 19 Nov 2020

HAL is a multi-disciplinary open access archive for the deposit and dissemination of scientific research documents, whether they are published or not. The documents may come from teaching and research institutions in France or abroad, or from public or private research centers.
L'archive ouverte pluridisciplinaire HAL, est destinée au dépôt et à la diffusion de documents scientifiques de niveau recherche, publiés ou non, émanant des établissements d'enseignement et de recherche français ou étrangers, des laboratoires publics ou privés. 


\title{
Romans Shape Today's Vegetation and Soils: Two Millennia of Land- Use Legacy Dynamics in Mediterranean Grasslands
}

\author{
Arne Saatkamp, ${ }^{1}$ Frédéric Henry, ${ }^{2}$ and Thierry Dutoit ${ }^{2 *} \odot$
}

${ }^{1}$ Aix Marseille Univ, Avignon Université, CNRS, IRD, IMBE, Faculté St-Jérôme - Case 421, 13397 Marseille Cedex 20, France; ${ }^{2}$ Avignon Université, Aix Marseille Univ, CNRS, IRD, IMBE, Site Agroparc, BP 1207, 84911 Avignon Cedex 9, France

\begin{abstract}
Archeological investigations in one of the most species-rich French Mediterranean dry grasslands (La Crau, Southern France) revealed a dense network of ancient sheep corrals dating from Roman to modern times. By analyzing soil chemistry and vegetation across abandonment dates spanning two millennia, we bring to light a persisting signature of Roman, eighteenth century and modern corrals on present-day ecosystems. Community composition and species-richness reflect time after abandonment of sheep stables and are linked to long-term persistence of eutrophication from historical sheep
\end{abstract}

Author contributions AS analyzed data; AS and TD wrote the paper. TD, AS and FH conceived and designed the study, TD and FH performed research.

*Corresponding author; e-mail: thierry.dutoit@univ-avignon.fr concentrations. Our data highlight changes in vegetation that persist two millennia after human impacts ceased. Small-scale pastoral legacies from Roman times continue to have significant impacts on present-day herbaceous plant communities. Our findings point to a need for greater consideration of persisting eutrophication in dry grasslands and of the conservation value of these long-term legacies.

Key words: Historical ecology; Land-use history; Species richness; Chronosequence; Old-field succession; Eutrophication.

\section{HighLighTs}

- Present-day Mediterranean grasslands are still impacted by Roman pastoral practices.

- Soil and vegetation are related to times after abandonment of former sheep corrals.

- Long-term eutrophication should be taken into account in current conservation systems.

\section{INTRODUCTION}

Land-use legacies have been shown to be a major determinant of vegetation and plant diversity in many different ecosystems (Dambrine and others 2007; Karlík and Poschlod 2014; Levis and others 
2017; Maezumi and others 2018), challenging the view that current ecological factors and functional relationships alone can explain present-day patterns of plant diversity (Purschke and others 2012). Recent syntheses argue that land-use legacies interact with ongoing climate change (Perring and others 2016). Understanding how land-use legacies impact biodiversity patterns is, moreover, increasingly important to evaluate how long human impacts might last (Russell 2019). It is therefore essential to determine whether long-term impacts follow similar patterns across ecosystems and to identify underlying processes.

The ecosystems where land-use legacies have been most thoroughly explored are temperate forest plant communities, which differ between recent and ancient forests (Brunet and others 2000; Bossuyt and others 2002; Graae and others 2003). In forests, impacts dating back as far as the Roman period have been clearly identified (Dupouey and others 2002; Vanwalleghem and others 2004; Dambrine and others 2007; Plue and others 2008). Dispersal limitation may contribute to these differences in vegetation composition, since some plant species are limited to ancient vegetation stands in Western Europe (Hermy and others 1999). Legacy effects have also been detected in soil seed banks (Plue and others 2008), underscoring long-term population dynamics as an alternative explanation for historical effects. The continuing differences in soil properties between ancient and recent vegetation stands are also thought to mediate the legacy effects of former agricultural practices (Dambrine and others 2007), suggesting that niche boundaries coincide spatially with historical remnants. Since nutrient leaching is faster in humid ecosystems such as forests than in dry grasslands (Rowarth and others 1985; Shand and Coutts 2006), effects can be expected to be different in semi-arid ecosystems (Rixon and Zorin 1978; Bahamonde and others 2017; Vinograd and others 2019). However, it remains unclear whether similar time scales and processes apply in other, especially more open, herbaceous ecosystems subjected to frequent grazing and fire.

Dry herbaceous ecosystems are among the most species-rich vegetation types, their characteristic species topping threatened species lists wherever evaluated (Poschlod and WallisDeVries 2002; WallisDeVries and others 2002). In Europe, open grasslands can be dated back to the Neolithic (Dutoit and others 2009; Robin and others 2018) and Bronze Age (Poschlod and Baumann 2010; Feurdean and others 2018). Nevertheless, most have experienced drastic changes in land-use due to re- cent agricultural intensification, fragmentation or abandonment (Pärtel and others 1999). As a consequence, most European temperate dry grasslands are today highly altered and continue to pay the extinction debt from recent land-use changes (Adriaens and others 2006). Moreover, important seed dispersal processes, for example, itinerant sheep flocks, have recently disappeared from the landscape (Poschlod and Bonn 1998; Ozinga and others 2009; Perez-Mendez and others 2016). Today, only Mediterranean dry grasslands in Southern Europe and Northern Africa still maintain traditional sheep grazing and associated high plant diversity (Rackham and Grove 2001; Gaillard and others 2008). Because some of these grasslands have not experienced drastic changes recently (Dutoit and others 2013b; Buisson and others 2020), they offer opportunities to study land-use legacy effects.

Recently abandoned arable fields have been identified as a major driver of plant biodiversity in contemporary grasslands (Römermann and others 2005; Cousins and Eriksson 2008; Karlík and Poschlod 2009, 2014). Studies on the legacy effects of arable farming on biodiversity considered timescales of up to a few hundred years since abandonment (Wells and others 1976; Gibson and Brown 1991; Dutoit and others 2003; Alard and others 2005; Römermann and others 2005; Forey and Dutoit 2012). At longer time-scales, evolution of species-richness and composition has been linked to human population density during Prehistoric times (Pärtel and Zobel 1999; Bruun and others 2001) up to the Late Iron Age (Pärtel and others 2007; Feurdean and others 2018). Moreover, species indicating the existence and historical status of grasslands were clearly identified (Karlík and Poschlod 2009). However, despite this highlighting of legacy effects on composition, little is known about the underlying processes.

Legacy effects of former agricultural uses on vegetation are thought to be mediated by differences in soil properties between ancient and recent vegetation stands (Römermann and others 2005; Helm and others 2019). Soil phosphorus seems to play a major role in linking soil pastoral legacies to persistent vegetation changes, based on lower mobility and higher accumulation rates (Saggar and others 1990). Nitrogen and calcium have also been shown to remain long-term in African livestock corrals (Augustine 2003; Porensky and Veblen 2015; Marshall and others 2018), a finding that requires evaluation in other ecosystems. Landuse legacies can also be detected using tracers such as the stable isotopes ${ }^{15} \mathrm{~N}$ and ${ }^{13} \mathrm{C}$ (Marshall and 
others 2018). Unfortunately, most data on land-use legacies are based on comparisons of a limited set of ages with an unimpacted sample, making it difficult to understand the temporal dynamics of ecosystem changes. Although several studies shed light on nutrient dynamics at the beginning of abandonment of sheep corrals (Leytem and Seefeldt 2008; Vinograd and others 2019), the dynamics of very long-term changes remain unclear due to a lack of longer time-series data. It appears extremely difficult to find suitable sites with similar land-use practices abandoned recurrently over longer timescales without overriding recent changes.

Here, we present a data set on human impacts with grazing abandonment dates spanning two millennia from Roman to modern times. Archeological investigations which identified and dated several hundred sheep stables enabled us to identify this time sequence (Badan and others 1995). All sites follow a similar spatial pattern: a sheep stable together with a corral surrounded by littlemodified but grazed areas. Geology, soil properties and land-use are very homogeneous over 55,000 ha of the study region; pastoral land-uses have changed but there has been no abandonment of them from the Neolithic to the present day (Buisson and Dutoit 2006).

We analyzed data on soil and vegetation to answer the following questions. (1) Can legacies from sheep grazing be detected in established vegetation and soil properties after two millennia? (2) Which soil and vegetation properties return to pre-impact values and which are still detectable today? (3) For the oldest impacts, which properties continue to differ from those of control plots? (4) What role do these long-term impacts play in today's threats to plant biodiversity?

\section{Materials ANd Methods}

\section{Study Site}

The study was carried out in La Crau, a dry treeless lowland plain covered by grasslands on more than 55,000 ha in Southern France. The geological substrate is alluvium from a fossil delta of Pleistocene origin $(-2$ to $-0.07 \mathrm{Ma})$, disconnected by tectonic uplift from the contributing river (Molliex and others 2013). Soils are shallow Haplic Cambisol with a high gravel content (40-60\%), and 50\% stone cover at the surface. Soil nutrients are low (especially $\mathrm{P}$ and $\mathrm{K}$ ), and there are no carbonates in the upper horizons. A thick carbonate layer accumulated in the lower horizons limits plant access to water. Soils were truncated by eolian erosion in the
Late Glacial (Bouteyre and Duclos 1994). Hot Mediterranean summers and low rainfall (500$600 \mathrm{~mm}$ ) make this one of the driest climates in mainland France. The grasslands in our study site contain no woody plants, and annual plants account for over $50 \%$ of plant diversity (Bourrelly and others 1983). The perennial tussock grass, Brachypodium retusum, represents $50 \%$ of standing biomass. From the Neolithic to today, grazing by itinerant sheep flocks has been the traditional landuse. During the last century, conversion of dry grasslands to arable fields and irrigated high production meadows decreased dry grasslands to 10,500 ha (Dutoit and others 2013a).

\section{Archeological Dating and Past Land-Use}

Soil charcoal investigations of Henry and others (2010) have confirmed the persistence of the open landscape from Roman times up to today and it proves that the whole area was subjected to continuous grazing from Roman period to today. Three periods are distinguished concerning the use of sheepfolds and their nearby corrals for animal husbandry (1) Modern sheepfolds $(100 \times 10 \mathrm{~m})$, some still in use today, built since the middle of the nineteenth century using clay-packed stone over the full height of the wall (Figure 1A, B). (2) Early eighteenth-century sheepfolds $(80 \times 8 \mathrm{~m})$, which were smaller and built using clay-packed stone only over the first meter of the base of the wall (Figure $1 \mathrm{C}$ ). These were abandoned during the nineteenth century because of sheep concentrations and increased flock sizes. (3) Roman sheepfolds $(50 \times 5 \mathrm{~m})$, still visible in the landscape as stone lines containing remnants of walls. The cob walls were built with small stones blended with earth, laid on rows of pebbles placed as headers for foundations (Figure 1D). Following abandonment, holes appear in the roofs after several years (Figure 1A), walls fall down after several decades (Figure 1B), and the ground is carried away by erosion after more or less one century (Figure lC). Two millennia later, only foundations are visible (Figure 1D). Common to all the sheepfolds is a corral built in front of the western wall, which protected the sheep from the frequent strong northwesterly winds. These corrals were used for handling sheep and for their health care (Badan and others 1995).

The soils and vegetation of 32 corrals randomly distributed in the study area were sampled. Nine are modern sheepfolds abandoned for between one (2008) and 40 years (1968). Thirteen are past sheepfolds abandoned between 1857 and World 


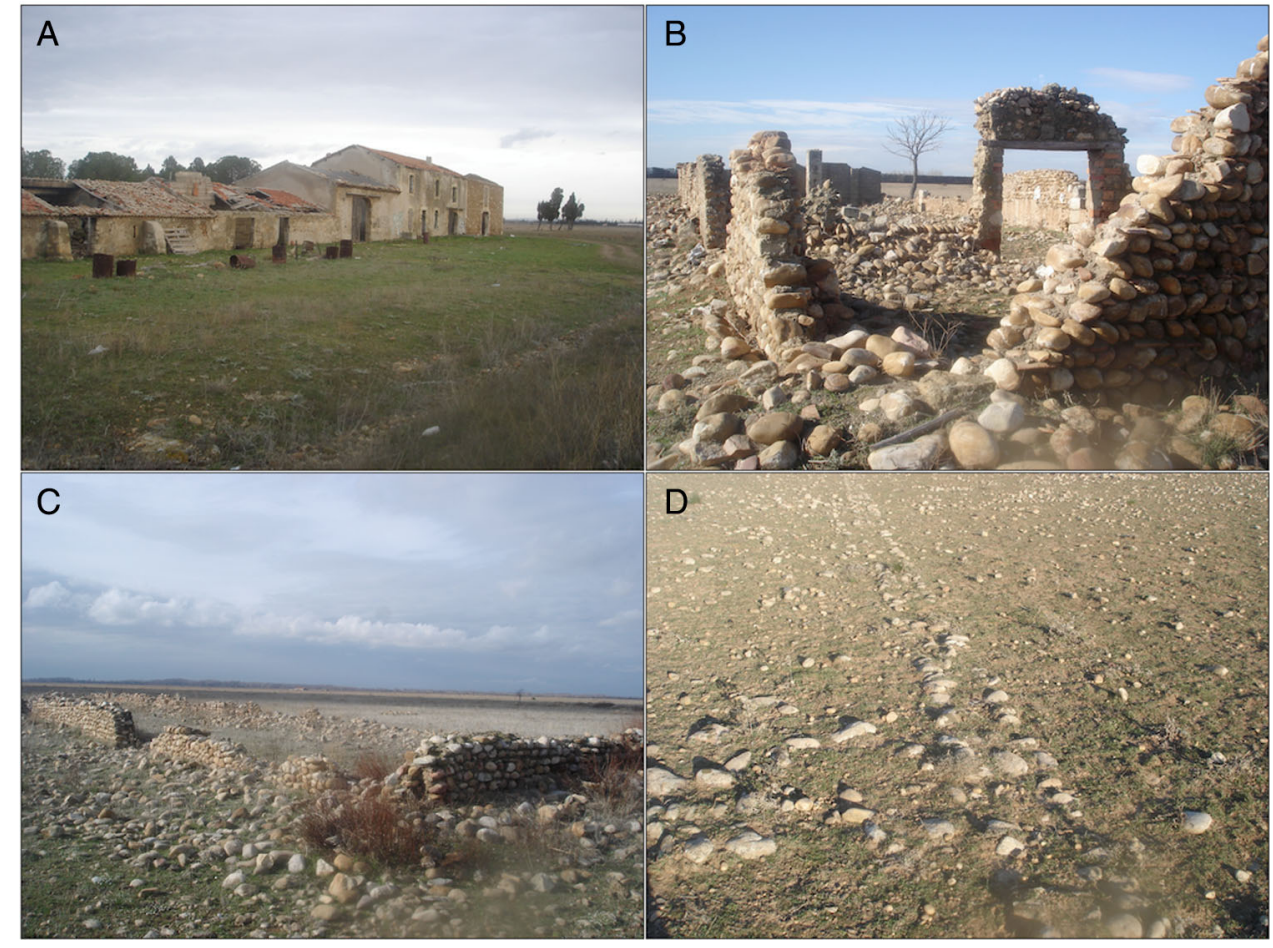

Figure 1. Sheepfolds studied in the Crau area (Southern France), (A) Modern sheepfold recently abandoned at the end of the twentieth century, (B) Modern sheepfold abandoned in the twentieth century, (C) eighteenth-century sheepfold abandoned in the nineteenth century and (D) Roman sheepfold abandoned around the fourth century (Photos Christelle Fameli, IMBE).

War I, 150 to 100 years of abandonment. The last group are ten Roman sheepfolds with abandonment dates spanning between 2000 (Early Roman Empire) and 1500 years BP (Late Roman Empire). Abandonment age of the Roman sheepfolds was estimated during archeological investigations (Badan and others 1995) and that of the past sheepfolds by using Cassini's historical map drawn in 1750 and the Staff map from 1856. We further estimated ages of abandonment of recent constructions using series of aerial photographs starting from 1944 and local surveys. Ten plots were randomly selected as controls in dry grassland vegetation situated at a distance from any present or archeological traces of former pastoral structures.

Vegetation and soil analyses were carried out at the base of the western wall of the sheepfolds corresponding to the interior of corrals. We studied vegetation composition in plots of $15 \mathrm{~m}^{2}$ $(15 \mathrm{~m} \times 1 \mathrm{~m})$ along the wall during spring 2008 at an abundance-dominance scale (Braun-Blanquet 1932), transformed to mean percentage prior to data analysis.

Five soil samples (200 g each) for each plot were taken and mixed before analysis. We sampled soils at $0-5 \mathrm{~cm}$ for unaltered sites and at $-5 \mathrm{~cm}$ to
$-10 \mathrm{~cm}$ at altered sites after removing materials imported by construction, animal excreta and manure to the upper layer of the soil. After drying and sieving $(200 \mu \mathrm{m})$, analyses of nutrients $(\mathrm{C}, \mathrm{N}$, $\mathrm{P}, \mathrm{K}, \mathrm{C}: \mathrm{N})$ and $\mathrm{pH}$ were carried out using the French standard for soil methods (Baize 1988), soil $\mathrm{C}$ reflecting soil organic matter content. We also studied soil ${ }^{15} \mathrm{~N}$ using mass spectrometry (INRAE, Nancy, France), with soil samples ground to less than $50 \mu \mathrm{m}$, because an increased ratio of ${ }^{15} \mathrm{~N}$ to total $\mathrm{N}$ was previously found to be correlated to intensity of former land-use (Koerner and others 1999).

We analyzed community composition of the 42 plots $\times 206$ species matrix using non-metrical multidimensional scaling (NMDS) as implemented in the metaMDS function in the package vegan for $\mathrm{R}$. Square-root-transformed Bray-Curtis distances were used and constrained to two axes. We subsequently tested correlation between multivariate axes, soil variables and age-classes using the envfit function with 9999 permutations and removing 8 plots without soil analyses. As a complement, a canonical correspondence analysis (Legendre and Legendre 1998) was performed on the 206 species $\times 34$ plots matrix, with a constraining matrix 
of seven soil variables (C, N, P and K content, C:N ratio, $\mathrm{pH}$ and $\left.\delta^{15} \mathrm{~N}\right) \times 34$ plots, using the function cca in package vegan of $\mathrm{R}$. The overall statistical significance of CCA was tested using a permutation (Legendre and others 2011). Plant species-richness for $15 \mathrm{~m}^{2}$, Sørensen's distance for all pairwise comparisons, and seven soil variables were compared via univariate tests using ANOVA followed by post hoc Tukey tests in all cases. To compare plots from Roman corrals and unaltered grasslands, Mann-Whitney or $t$ tests were used as indicated. Frequency of species between strata was analyzed using the signassoc permutation test (Cáceres and Legendre 2009) in R package indicspecies, with 9999 permutations.

\section{RESUlts}

NMDS drew a clear picture of the age gradient of grassland vegetation, from active corrals through those recently abandoned to those of Roman age, along its first axis (Figure 2A, C). The second axis of NMDS further separated unaltered grasslands from corrals abandoned since Roman times. When soil data was compared with NMDS, the first axis turned out to be strongly positively correlated to fertility variables, and both axes explained a large proportion of the variance in soil $\mathrm{C}, \mathrm{N}, \mathrm{P}$ and $\mathrm{K}$ content $\left(R^{2}=0.63,0.69, \quad 0.85\right.$ and 0.85 , all $p<0.001)$ as well as in $\mathrm{pH}$ and $\delta^{15} \mathrm{~N}\left(R^{2}=0.36\right.$ and $0.70, p<0.001$ ), but not the variance in C:N ratio $\left(R^{2}=0.08, p=0.288\right)$. Moreover, age-classes were significantly related to vegetation as measured by correlation with NMDS axes $\left(R^{2}=0.74\right.$, $p<0.001)$. When axes were taken separately, soil variables showed significant correlations with the first but not the second axis, and only age-classes showed a significant relationship to both the first and the second axis $\left(R^{2}=0.24, p=0.04\right)$. CCA revealed a first axis $(44 \%$ of total variation) strongly related to fertility and correlated with the period of corral abandonment (Figure 2C). Ruderal vegetation of the more recent former corrals was at an intermediate stage between the nitrophilous vegetation sampled in active corrals with high levels of $\mathrm{pH}$ and soil nutrients $(\mathrm{C}, \mathrm{N}, \mathrm{P}, \mathrm{K}$ content, $\delta^{15} \mathrm{~N}$ ) and the stress-tolerant vegetation sampled in the former Roman corrals or unaltered grasslands with higher soil $\mathrm{C}: \mathrm{N}$ ratios. The second axis accounted for $13 \%$ of variance and CCA statistical significance, with a total inertia of 2.59, was high $(p<0.001)$ according to the results of the permutation test. The soil fertility gradient revealed by multivariate analysis was also confirmed by the univariate tests of the different soil variables measured (see below).

Eleven plant species were significantly more common in vegetation on former Roman corrals than on all other plots in randomization tests at $p<0.01$ : Bellis sylvestris, Carlina corymbosa, Euphorbia falcata, Filago gallica, Linum trigynum, Plantago bellardii, Poa bulbosa, Reichardia picroides, Sideritis romana, Thymus vulgaris and Trifolium subterraneum. Twelve ruderal species (Amaranthus deflexus, Chenopodium album, Chenopodium murale, Convolvulus arvensis, Diplotaxis tenuifolia, Ecballium elaterium, Hordeum murinum, Lepidium campestre, Malva sylvestris, Marubium vulgare, Rumex pulcher and Stellaria media) were significantly positively associated $(p<0.01)$ with active sheep corrals. Four mesophytic species were associated with recently abandoned sheep corrals at $p<0.01$ (Asphodelus ayardii, Dactylis glomerata, Eryngium campestre and Medicago monspeliaca). Four oligotrophic grasses (Aira cupaniana, Brachypodium distachyon, B. retusum, Anisantha rubens, Taeniaterum caput-medusae) and the two annual herbs Euphorbia exigua and Linaria arvensis were significantly more common in unaltered grasslands.

Both the more recently abandoned and the Roman corrals had higher species-richness than the control dry grassland plots, even after 15002000 years of abandonment (Figure 3A). Significant differences in species composition among the four types of vegetation were revealed by the analysis of dissimilarities $\left(F=7.4 \quad R^{2}=0.42\right.$, $p<0.001)$ and subsequent permutation tests revealed significant differences among all groups $(p<0.01)$. Comparison of plots in the unaltered grasslands with those containing former corrals showed decreasing dissimilarities, from active through recently abandoned to Roman sheep corrals, the latter remaining significantly different from dissimilarities within the unaltered grasslands (Figure 3B).

Carbon, nitrogen, phosphorus and potassium content and $\delta^{15} \mathrm{~N}$ decreased, from modern corrals through recently abandoned and Roman corrals to unaltered grassland. Moreover, $\mathrm{pH}$ values of modern and recently abandoned corrals were weakly basic, with a mean $\mathrm{pH}$ of 7.7. They were significantly higher than those of the former Roman corrals and the controls, which were weakly acidic with a mean $\mathrm{pH}$ of 6.8 . Seeking to establish the higher soil fertility of Roman corrals compared to unaltered grassland using $U$-tests, we found carbon and phosphorous content to be marginally significantly higher 2000 years after their abandonment (Figure 4). C:N values were higher in Roman sheep 

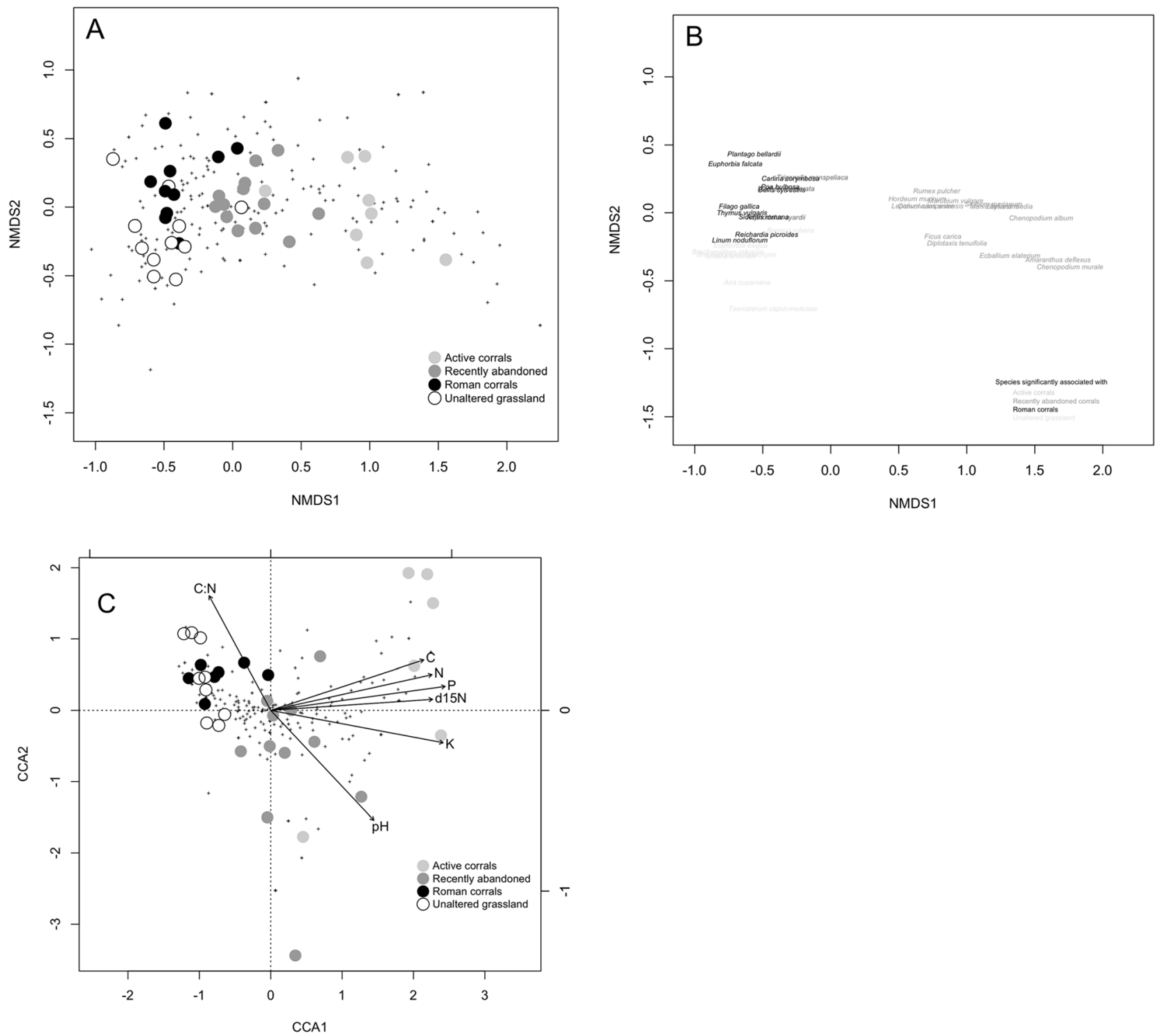

Figure 2. Nonmetrical multidimensional scaling (NMDS) of plant community composition of (A) plots on active sheep corrals, recently abandoned sheep corrals, Roman sheep corrals and unaltered grasslands, centers of plant species positions are marked '+'; (B) NMDS-positions of species significantly associated with one of the three plot types according to randomization tests $(p<0.01)$; $(\mathbf{C})$ Canonical correspondence analysis (CCA) of vegetation composition of plots and soil variables $\left(\mathrm{C}, \mathrm{N}, \mathrm{P}, \mathrm{K}\right.$ content, $\mathrm{C}: \mathrm{N}$ ratio, $\mathrm{pH}$ and $\left.\delta^{15} \mathrm{~N}\right)$ of active sheep corrals, recently abandoned sheep corrals, Roman sheep corrals and unaltered grasslands; centers of plant species positions are marked ' + '.

corrals than in unaltered grasslands or in more recent corrals.

\section{Discussion}

Our study reveals that soil and vegetation in Mediterranean dry grasslands are still impacted by former sheep corrals two millennia after abandonment. Soil modifications from Roman times that persist in our system include higher phosphorous and $\mathrm{C}: \mathrm{N}$ values as well as higher organic matter (soil C content). Legacies from abandonment in the nineteenth- and twentieth-century concern soil $\delta^{15} \mathrm{~N}$, pH and potassium, distinguishing these plots from Roman corrals and unaltered grasslands. It appears that soil organic matter and nutrients have not yet been redistributed spatially, and that a concentration gradient from abandoned sheep corrals to unaltered grasslands persists long after abandonment. Additionally, our data from Mediterranean dry grasslands indicate that soil phosphorus is more persistent than nitrogen. 

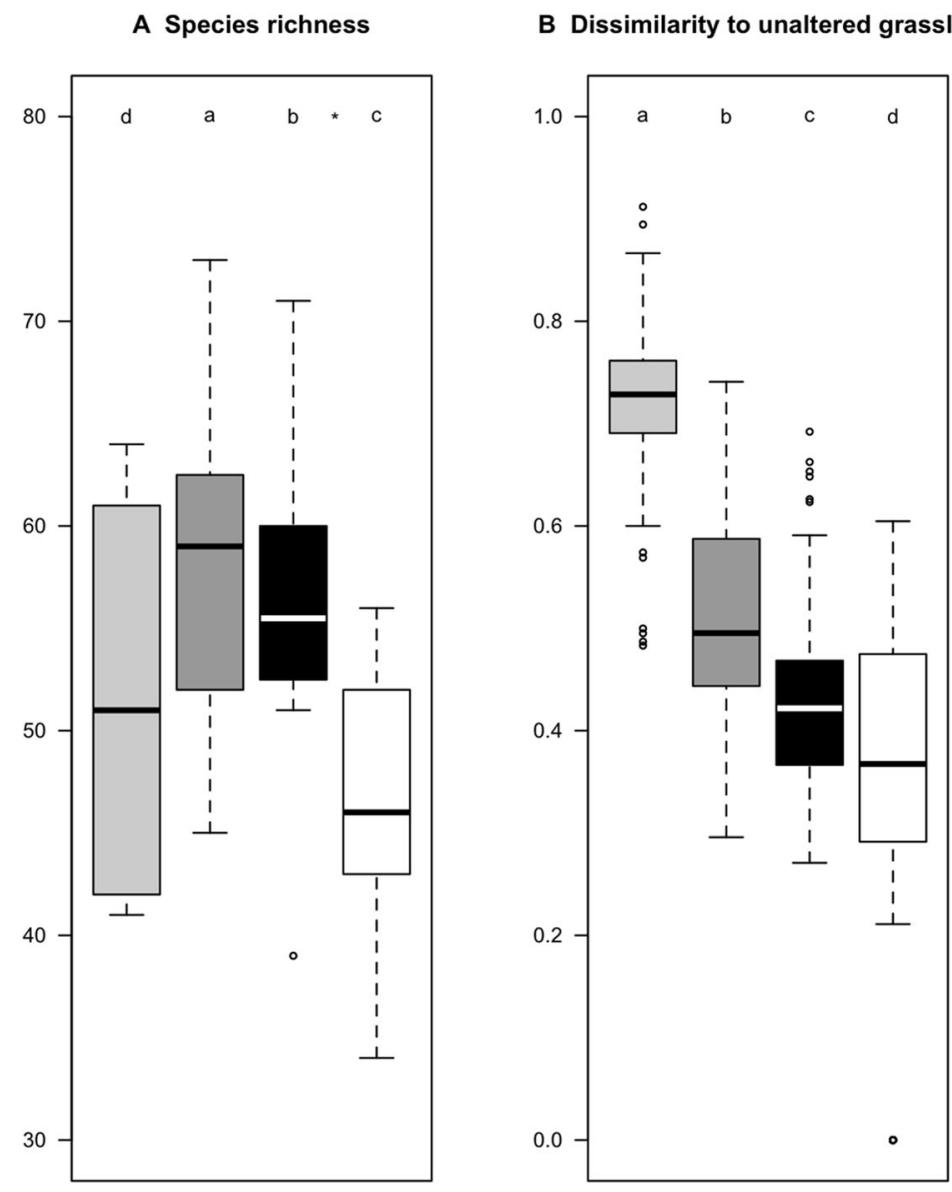

Figure 3. (A) Species richness in vegetation on active (A), recently abandoned (D) and Roman (R) sheep corrals as well as unaltered grasslands $(\mathrm{X})$. ${ }^{*}$ Significant $t$ test $(p<0.01)$ of higher richness in Roman corrals compared to unaltered grasslands. (B) compositional dissimilarities measured by Sørensen index differ significantly between sheep corrals and unaltered grasslands (ANOVA, $F=114.9, p<0.001$ ). Letters above boxes indicate significant differences at $p<0.05$ in Tukey's post hoc test. Black box represents dissimilarities within the group of plots in unaltered grasslands. Box plots represent distribution of data as follows: dash in the box denotes the median, boxes are limits enclosing the interquartile range between first and third quartile, whiskers extend to data points within 1.5 times the interquartile range, beyond which open circles denote outliers.

Redistribution or site-specific concentration of phosphorous and other nutrients in pasture systems is linked to the high concentration of organic matter in dung (Shahack-Gross 2011). Once mineralized and incorporated into the soil, phosphorous is redistributed slowly compared to $\mathrm{C}$ and $\mathrm{N}$, as shown in experimental data from grassland soils (Tiessen and others 1982), probably due to its association with mineral soil particles (Shi and Schulin 2018). Long-term nutrient retention in dry soils is exacerbated by high dung levels created when sheep are concentrated in corrals (Augustine 2003; Marshall and others 2018). This has been linked to slow leaching of nutrients (Austin and Vitousek 1998; Scott and others 1999; Parfitt and others 2003; Alberti and others 2011), and to lower levels of nitrification in dry soils (Carreira and others 1994) leading to higher nitrogen stocks (Robertson and Vitousek 1981; Bonet 2004). Although initially increased nitrogen levels rapidly decrease in the first decades after abandonment in temperate pastures (Leytem and Seefeldt 2008; Vinograd and others 2019), significant differences persist after millennia of abandonment in African savannah ecosystems (Marshall and others 2018). Although many nutrients in defecations of herbivores are rapidly redistributed in the ecosystem (Augustine 2003; Schnyder and others 2010), this is not the case for phosphorus in our system.

Elevated phosphorus levels have been reported as effects of land-use history in dry grasslands, but on relatively short timescales (Wells and others 1976; Gibson and Brown 1991; Römermann and others 2005; Forey and Dutoit 2012). Phosphorus 

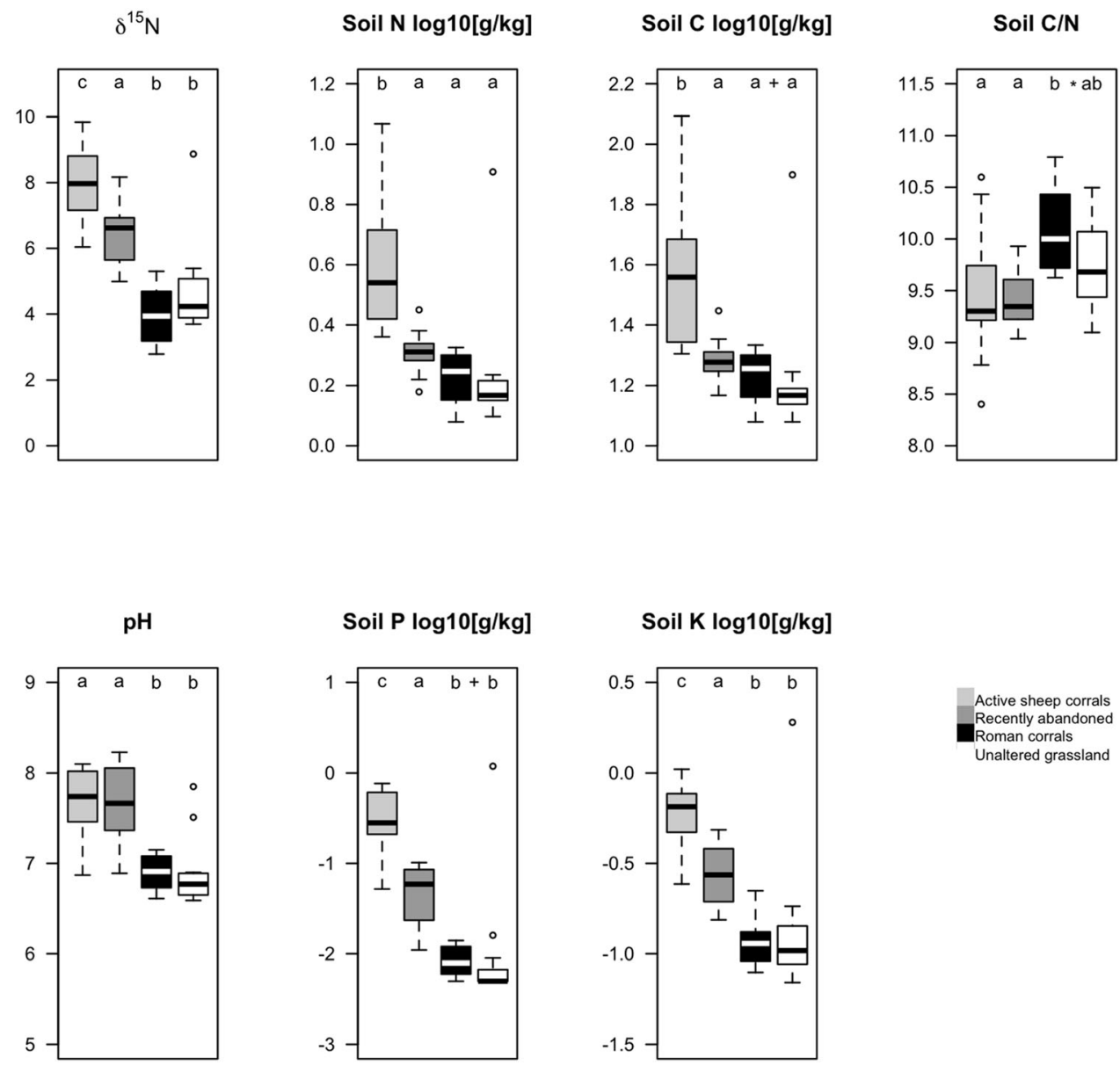

Figure 4. Soil variables in active sheep corrals (A), recently abandoned sheep corrals (D), Roman sheep corrals (R) and unaltered grasslands $(\mathrm{X})$. Letters indicate significant differences in Tuckey's post hoc test at $p<0.05$; results of testing for greater fertility values in Roman corrals compared to unaltered grasslands are indicated by * (Mann-Whitney, $p<0.05)$ and $+(p<0.1$, for marginally significant $)$.

and carbon have also been identified as good indicators of past land-uses (Verheyen and others 1999). Elevated phosphorus and carbon content can clearly be considered a consequence of a process of increasing sheep concentration along a gradient from unaltered dry grasslands to the pastoral legacy of the remaining corrals (Compton and Boone 2000; Augustine 2003). Because phosphorus is a strong driver of vegetation composition (Hopper 2009; Stiles and others 2017; Helm and others 2019), it may explain long-term persistent vegetation differences between historic sheep corrals and unaltered grasslands.

Nevertheless, not all indicators of past land-use remain at elevated levels over such long timescales. For example, we did not find significant differences between the former Roman corrals and control plots for $\delta^{15} \mathrm{~N}$. Nitrogen is known to be more mobile in soils (Tiessen and others 1982; Elliott 1986; Leytem and Seefeldt 2008; Vinograd and others 2019). Nitrogen losses are linked to organic matter losses (Shi and Schulin 2018), and it is more easily recovered from soil by plants, enabling locally increased nitrogen levels to disappear more rapidly. Recently abandoned sheep corrals show significantly increased $\delta^{15} \mathrm{~N}$ values. The higher $\delta^{15} \mathrm{~N}$ values in sheep dung result from animal proteins rich in ${ }^{15} \mathrm{~N}$ (Shahack-Gross and others 2008; Macharia and others 2012). Animal dung loses volatile fractions of nitrogen, which increase $\delta^{15} \mathrm{~N}$ values (Ambrose 1991) and can be maintained over millennia in dung deposits in dry tropical environments (Marshall and others 2018). Because we did not sample specifically dung-derived sediments, our $\delta^{15} \mathrm{~N}$ values may be underestimated. However, even our unaltered grasslands in Southern France show comparatively low $\delta^{15} \mathrm{~N}$ values that are indicative of either more mobile nitrogen or a much younger grazing system compared to East Africa. Persistent traces of past land-use vary 
between ecosystems in a complex manner, calling for closer examination of the mechanisms that maintain indicators of past land-uses on long timescales.

One of the processes modifying mobility of elements within ecosystems is spatial redistribution by grazers (Shand and Coutts 2006; Cameron and others 2013; Selbie and others 2015). In our system, grazing was continuous over large areas, with little variation in stocking rates, as studies on archeological data on sheepfold size and number suggest (for example, Badan and others 1995). Spatial redistribution by, for instance, grazing in abandoned corrals and dispersal of excreta, decreases local nutrients, which might also explain the contrast between our data and findings from forest and savannah ecosystems where former agricultural practices were abandoned (Koerner and others 1999; Jussy and others 2002; Marshall and others 2018). Increased levels of C:N increase microbial activity, nutrient cycling and nitrification in soils (Haney and others 2012). Furthermore, differences among soil types determine how landuse modifies soil $\mathrm{pH}$ and how long these modifications may last (Plue and others 2008). In our case, $\mathrm{N}$-mineralization, denitrification and uptake by vegetation increase the $\mathrm{C}: \mathrm{N}$ ratio and significantly decrease the soil $\mathrm{pH}$ to weakly acidic after 50-100 years of abandonment. Similar results have been found in forest soils around Roman-era farms in central Europe (Dupouey and others 2002; Dambrine and others 2007; Plue and others 2008). Differing soil acidity levels and varying rates of change strongly impact the persistence of pastoral legacies in different ecosystems. Idiosyncrasies in type, position and timing make pastoral legacies a major source of small-scale variability and unicity in grassland ecosystems.

Ruderal plants absent from unaltered dry grasslands dominate in areas with nutrient accumulation, and decrease during the first decades after abandonment. This first phase of vegetation change after abandonment can be linked to rapidly decreasing nitrogen by denitrification and spatial redistribution (Leytem and Seefeldt 2008; Vinograd and others 2019). This phase also shows a significant increase in species-richness compared to active sheep corrals and even to unaltered grasslands. Ruderal plants on abandoned sheep corrals are known to be particularly productive (Porensky and Veblen 2015; Vinograd and others 2019), an effect that persists long-term in African savannahs and is exploited by herbivores (Marshall and others 2018 ). Though more than $70 \%$ of typical grassland species are absent in the first phase, many ruderal and mesotrophic species co-exist, despite high dissimilarities with unimpacted vegetation. One hundred to 150 years after abandonment, speciesrichness reaches its maximum. At this stage, the species composition of plant communities is at an intermediate stage between that of active corrals and of corrals abandoned since Roman times, and includes many ruderal and stress-tolerant species with less extreme nutrient requirements (for example, Calamintha nepeta, Medicago minima, Verbascum sinuatum, Onopordon illyricum). Some species known to be cultivated specifically for veterinary use by shepherds during the eighteenth century, such as Plumbago europaea, also appear in this type of vegetation. We were surprised to discover that Roman corrals continue to show higher speciesrichness and different composition compared to unaltered grasslands, two millennia after abandonment. Interestingly, among all the vegetation types studied, some species show their maximum frequencies on surfaces abandoned 1500 to 2000 years ago (for example, Bellis sylvestris, Plantago bellardii and Euphorbia falcata) and are less frequent in unaltered grasslands. The long periods of abandonment of sheep corrals since Roman times are further characterized by the arrival of numerous stress-tolerant species typical of Mediterranean dry grasslands (for example, Brachypodim retusum, Brachypodium distachyon, Thymus vulgaris) combined with the persistence of ruderals that are absent from unimpacted grasslands (Rubus ulmifolius, Pardoglossum cheiriifolium, Onopordon illyricum, Hordeum murinum, Crepis bursifolia and Capsella bursa-pastoris). Finally, unaltered grasslands show lower species-richness and an absence of highly productive species, suggesting that pastoral legacies in the Mediterranean lead to hotspots of biodiversity and ecosystem services, similar to African sheep corrals (Porensky and Veblen 2015; Marshall and others 2018).

Our data indicate that plant community composition and species-richness remain altered 2000 years after corral abandonment in grasslands. Similar results have been found for forest ecosystems in temperate Europe (Dupouey and others 2002; Dambrine and others 2007; Plue and others 2008). Nevertheless, it is astonishing that such effects can still be clearly identified in grasslands, where the maintenance of grazing and fire practices over centuries could be expected to redistribute nutrients and mask differences in vegetation. Redistribution of nutrients in our system is particularly slow, with species-richness remaining higher on sheep corrals abandoned in Roman times than on unaltered grasslands. Dif- 
ferences found in community composition, and attributable to land-use legacies, may be driven by persisting effects on soil parameters (Römermann and others 2005; Plue and others 2008). This interpretation is based on a causal link between vegetation and the relevant soil parameters, and differs from biotically driven low species-turnover. Low species-turnover may be linked to plant age. However, because most species characteristic of Roman sheep corrals are annual plants or shortlived perennials, this explanation seems less likely. The very low resilience of dry grasslands following changes in pastoral practices even after several millennia of abandonment could also be linked to the inability of typical dry grassland species to colonize new habitats or persist in the soil seed bank (Buisson and others 2006; Metzner and others 2017). Similar results have been found for plants of ancient forests (Verheyen and Hermy 2001) or plants of grasslands, which were have not been cultivated during the nineteenth century (Hutchings and Booth 1996).

The detailed examination of vegetation changes complements the exploration of soil nutrient dynamics after abandonment for several reasons. (1) Vegetation composition is the main driver of selective grazing by livestock (Augustine and McNaughton 1998; Bee and others 2009), influencing herd-owner decisions (Augustine 2003; Porensky and Veblen 2015). (2) Changes in composition and diversity have cascading effects on consumers, predators and detritivorous insect communities (Fadda and others 2007), as well as on pollinators (Lhotte and others 2014; Cusser and others 2016). (3) Vegetation itself acts as a separate compartment in the nutrient cycle, since it can store carbon, nitrogen and phosphorous in the ecosystem (Bobbink and others 1989; Peri and Lasagno 2010). Examining vegetation composition and structure is hence an important step toward understanding how pastoral legacies affect the entire ecosystem.

Our findings point to the need to consider the long-term impacts of human activities, shown to persist for over two millennia through increased nutrient values and differences in vegetation. Together with earlier studies, our study suggests that persistent effects on today's vegetation can be linked to persistent soil property legacies. Because pastoral legacies impact vegetation and many other compartments of ecosystems, including livestock and humans, understanding their historical effects will help to inform sheep-owners' decisions on practices and rangeland management. Moreover, under the current renewal of sheep grazing prac- tices for the conservation of grasslands, our data call for consideration of the long-term impacts of certain practices on small-scale oligotrophic habitats. Finally, historical livestock corrals have important consequences for today's ecosystem functioning, due to their higher productivity and contribution to local biodiversity.

\section{ACKNOWLEDGEMENTS}

We thank local nature conservation authorities, CEN-PACA, Crau Nature Reserve and Department of Culture and Archaeology (DRAC) for authorizing site access; we are grateful to Otello Badan and Gaetan Congès for identifying archaeological remains and to Jean-Paul Dupouey for the ${ }^{15} \mathrm{~N}$ analyses at INRAE (Nancy, France). We thank Marjorie Sweetko for English language revision.

\section{REFERENCES}

Adriaens D, Honnay O, Hermy M. 2006. No evidence of a plant extinction debt in highly fragmented calcareous grasslands in Belgium. Biological Conservation 133:212-24.

Alard D, Chabrerie O, Dutoit T, Roche P, Langlois E. 2005. Patterns of secondary succession in calcareous grasslands: can we distinguish the influence of former land uses from present vegetation data? Basic and Applied Ecology 6:161-73.

Alberti G, Leronni V, Piazzi M, Petrella F, Mairota P, Peressotti A, Piussi P, Valentini R, Gristina L, La Mantia T, Novara A, Rühl J. 2011. Impact of woody encroachment on soil organic carbon and nitrogen in abandoned agricultural lands along a rainfall gradient in Italy. Regional Environmental Change 11:917-24.

Ambrose SH. 1991. Effects of diet, climate and physiology on nitrogen isotope abundances in terrestrial foodwebs. Journal of Archaeological Science 18:293-317.

Augustine DJ. 2003. Long-term, livestock-mediated redistribution of nitrogen and phosphorus in an East African savanna. Journal of Applied Ecology 40:137-49.

Augustine DJ, McNaughton SJ. 1998. Ungulate effects on the functional species composition of plant communities: herbivore selectivity and plant tolerance. Journal of Wildlife Management 1165-83.

Austin AT, Vitousek PM. 1998. Nutrient dynamics on a precipitation gradient in Hawai'i. Oecologia 113:519-29.

Badan O, Brun JP, Congès G. 1995. Les bergeries Romaines de la Crau d'Arles. Gallia 52:263-310.

Bahamonde HA, Gargaglione VB, Peri PL. 2017. Sheep faeces decomposition and nutrient release across an environmental gradient in Southern Patagonia. Ecologia Austral 27:18-28.

Baize D. 1988. Guide des analyses courantes en pédologie. Paris: INRA.

Bee JN, Tanentzap AJ, Lee WG, Lavers RB, Mark AF, Mills JA, Coomes DA. 2009. The benefits of being in a bad neighbourhood: plant community composition influences red deer foraging decisions. Oikos 118:18-24.

Bobbink Rd, Den Dubbelden K, Willems JH. 1989. Seasonal dynamics of phytomass and nutrients in chalk grassland. Oikos 216-24. 
Bonet A. 2004. Secondary succession of semi-arid Mediterranean old-fields in south-eastern Spain: insights for conservation and restoration of degraded lands. Journal of Arid Environments 56:213-33.

Bossuyt B, Heyn M, Hermy M. 2002. Seed bank and vegetation composition of forest stands of varying age in central Belgium: consequences for regeneration of ancient forest vegetation. Plant Ecology 162:33-48.

Bourrelly M, Borel L, Devaux JP, Louis-Palluel J, Archiloque A. 1983. Dynamique annuelle et production primaire nette de l'écosystème steppique de Crau (Bouches du Rhône). Biologie-Écologie Méditerranéenne 10:55-82.

Bouteyre G, Duclos G. 1994. Carte pédologique de la France à $1 /$ 100 000. Arles N-22, Service d'Étude des Sols et de la Carte pédologique de France, Orléans.

Braun-Blanquet J. 1932. Plant sociology; the study of plant communities. New York: McGraw-Hill.

Brunet J, von Oheimb G, Diekmann M. 2000. Factors influencing vegetation gradients across ancient-recent woodland borderlines in southern Sweden. Journal of Vegetation Science 11:515-24.

Bruun HH, Fritzbøger B, Rindel PO, Hansen UL. 2001. Plant species richness in grasslands: the relative importance of contemporary environment and land-use history since the Iron Age. Ecography 24:569-78.

Buisson E, De Almeida T, Durbecq A, Arruda AJ, Vidaller C, Alignan JF, Shizen TPT, Hess MCM., Pavon D, Isselin-Nondedeu F, Jaunatre R, Moinardeau C, Young TP, Mesléard F, Dutoit T, Blight O, Bischoff A. 2020. Key issues in NorthWestern Mediterranean dry grassland restoration. Restoration Ecology. https://doi.org/10.1111/rec.13258.

Buisson E, Dutoit T. 2006. Creation of the natural reserve of La Crau: implications for the creation and management of protected areas. Journal of Environmental Management 80:31826.

Buisson E, Dutoit T, Torre F, Römermann C, Poschlod P. 2006. The implications of seed rain and seed bank patterns for plant succession at the edges of abandoned fields in Mediterranean landscapes. Agriculture Ecosystems \& Environment 115:6-14.

Cáceres MD, Legendre P. 2009. Associations between species and groups of sites: indices and statistical inference. Ecology 90:3566-74.

Cameron KC, Di HJ, Moir JL. 2013. Nitrogen losses from the soil/plant system: a review. Annals of Applied Biology $162: 145-73$.

Carreira JA, Niell FX, Lajtha K. 1994. Soil nitrogen availability and nitrification in Mediterranean shrublands of varying fire history and successional stage. Biogeochemistry 26:189-209.

Compton JE, Boone RD. 2000. Long-term impacts of agriculture on soil carbon and nitrogen in New England forests. Ecology $81: 2314-30$

Cousins SAO, Eriksson O. 2008. After the hotspots are gone: land use history and grassland plant species diversity in a strongly transformed agricultural landscape. Applied Vegetation Science 11:365-74.

Cusser S, Neff JL, Jha S. 2016. Natural land cover drives pollinator abundance and richness, leading to reductions in pollen limitation in cotton agroecosystems. Agriculture, Ecosystems \& Environment 226:33-42.

Dambrine E, Dupouey JL, Laüt L, Humbert L, Thinon M, Beaufils T, Richard H. 2007. Present forest biodiversity pat- terns in France related to former Roman agriculture. Ecology 88:1430-9.

Dupouey JL, Dambrine E, Laffite JD, Moares C. 2002. Irreversible impact of past land use on forest soils and biodiversity. Ecology 83:2978-84.

Dutoit T, Buisson E, Fadda S, Henry F, Coiffait-Gombault C, Jaunatre R, Alignan JF, Masson S, Bulot A. 2013a. The pseudo-steppe of La Crau (South-Eastern France): origin, management and restoration of a Mediterranean rangeland. Traba J, Morales M editors. Steppe Ecosystems: Biological Diversity, Management and Restoration. New York: Nova Publishers, pp 287-301.

Dutoit T, Gerbaud E, Buisson E, Roche P. 2003. Dynamics of a weed community in a cereal field created after ploughing a seminatural meadow: role of the permanent seed bank. Ecoscience 10:225-35.

Dutoit T, Jaunatre R, Buisson E. 2013b. Mediterranean steppe restoration in France. Clewel A, Aronson J editors. Ecological Restoration: Principles, Values, and Structure of an Emerging Profession. Washington: Island Press, pp. 60-4.

Dutoit T, Thinon M, Talon B, Buisson E, Alard D. 2009. Sampling soil wood charcoals at a high spatial resolution: a new methodology to investigate the origin of grassland plant communities. Journal of Vegetation Science 20:349-58.

Elliott ET. 1986. Aggregate Structure and Carbon, Nitrogen, and Phosphorus in Native and Cultivated Soils 1. Soil Science Society of America Journal 50:627-33.

Fadda S, Orgeas J, Ponel P, Buisson E, Torre F, Dutoit T. 2007. Past cultivation is a factor driving organization of dry grassland ground-active beetle communities. Environmental Conservation 34:132-9.

Feurdean A, Ruprecht E, Molnár Z, Hutchinson SM, Hickler T. 2018. Biodiversity-rich European grasslands: ancient, forgotten ecosystems. Biological Conservation 228:224-32.

Forey E, Dutoit T. 2012. Vegetation, soils and seed banks of limestone grasslands are still impacted by former cultivation one century after abandonment. Community Ecology 13:194202.

Gaillard M-J, Sugita S, Bunting J, Dearing J, Bittmann F. 2008. Human impact on terrestrial ecosystems, pollen calibration and quantitative reconstruction of past land-cover. Springer.

Gibson CWD, Brown VK. 1991. The effects of grazing on local colonization and extinction during early succession. Journal of Vegetation Science 2:291-300.

Graae BJ, Sunde PB, Fritzbøger B. 2003. Vegetation and soil differences in ancient opposed to new forests. Forest Ecology and Management 177:179-90.

Haney RL, Franzluebbers AJ, Jin VL, Johnson M-V, Haney EB, White MJ, Harmel RD. 2012. Soil organic C:N vs. water-extractable organic C:N. Open Journal of Soil Science 2:269-74.

Helm J, Dutoit T, Saatkamp A, Bucher SF, Leiterer M, Römermann C. 2019. Recovery of Mediterranean steppe vegetation after cultivation: legacy effects on plant composition, soil properties and functional traits. Applied Vegetation Science 22:71-84.

Henry F, Talon B, Dutoit T. 2010. The age and history of the French Mediterranean steppe revisited by soil wood charcoal analysis. The Holocene 20:25-34.

Hermy M, Honnay O, Firbank L, Grashof-Bokdam C, Lawesson JE. 1999. An ecological comparison between ancient and other forest plant species of Europe, and the implications for forest conservation. Biological Conservation 91:9-22. 
Hopper SD. 2009. OCBIL theory: towards an integrated understanding of the evolution, ecology and conservation of biodiversity on old, climatically buffered, infertile landscapes. Plant and Soil 322:49-86.

Hutchings MJ, Booth KD. 1996. Studies of the feasibilityof recreating chalk grassland vegetation on ex-arable land. I. The potential roles of the seed bank and the seed rain. Journal of Applied Ecology 33:1 182-90.

Jussy J-H, Koerner W, Dambrine É, Dupouey J-L, Benoît M. 2002. Influence of former agricultural land use on net nitrate production in forest soils. European Journal of Soil Science 53:367-74.

Karlík P, Poschlod P. 2009. History or abiotic filter: which is more important in determining species composition of calcareous grasslands? Preslia 81:321-40.

Karlík P, Poschlod P. 2014. Soil seed-bank composition reveals the land-use history of calcareous grasslands. Acta Oecologica 58:22-34.

Koerner W, Dambrine E, Dupouey JL, Benoît M. 1999. $\delta 15 \mathrm{~N}$ of forest soil and understorey vegetation reflect the former agricultural land use. Oecologia 121:421-5.

Legendre P, Legendre L. 1998. Numerical Ecology.

Legendre P, Oksanen J, ter Braak CJ. 2011. Testing the significance of canonical axes in redundancy analysis. Methods in Ecology and Evolution 2:269-77.

Levis C, Costa FR, Bongers F, Peña-Claros M, Clement CR, Junqueira AB, Neves EG, Tamanaha EK, Figueiredo FO, Salomão RP. 2017. Persistent effects of pre-Columbian plant domestication on Amazonian forest composition. Science 355:925-31.

Leytem AB, Seefeldt SS. 2008. Impact of sheep bedding on soil nutrient dynamics in the Centennial Mountains of Montana and Idaho. Soil Science 173:503-10.

Lhotte A, Affre L, Saatkamp A. 2014. Are there contrasted impacts of urbanization and land uses on population persistence? The case of Teucrium pseudochamaepitys, an endangered species in Southern France. Flora 209:484-90.

Macharia AN, Uno KT, Cerling TE, Brown FH. 2012. Isotopically distinct modern carbonates in abandoned livestock corrals in northern Kenya. Journal of Archaeological Science 39:2198205.

Maezumi SY, Alves D, Robinson M, de Souza JG, Levis C, Barnett RL, de Oliveira EA, Urrego D, Schaan D, Iriarte J. 2018. The legacy of 4,500 years of polyculture agroforestry in the eastern Amazon. Nature plants 4:540.

Marshall F, Reid REB, Goldstein S, Storozum M, Wreschnig A, Hu L, Kiura P, Shahack-Gross R, Ambrose SH. 2018. Ancient herders enriched and restructured African grasslands. Nature 561:387-90.

Metzner K, Gachet S, Rocarpin P, Saatkamp A. 2017. Seed bank, seed size and dispersal in moisture gradients of temporary pools in Southern France. Basic and Applied Ecology 21:1322.

Molliex S, Siame LL, Bourlès DL, Bellier O, Braucher R, Clauzon G. 2013. Quaternary evolution of a large alluvial fan in a periglacial setting (Crau Plain, SE France) constrained by terrestrial cosmogenic nuclide (10Be). Geomorphology 195:45-52.

Ozinga WA, Römermann C, Bekker RM, Prinzig A, Tamis WLM, Schaminée JHJ, Hennekens SM, Thompson K, Poschlod P, Kleyer M, Bakker JP, van Groenendael JM. 2009. Dispersal failure contributes to plant losses in NW Europe. Ecology Letters 12:66-74.

Parfitt RL, Scott NA, Ross DJ, Salt GJ, Tate KR. 2003. Land-use change effects on soil $\mathrm{C}$ and $\mathrm{N}$ transformations in soils of high $\mathrm{N}$ status: comparisons under indigenous forest, pasture and pine plantation. Biogeochemistry 66:203-21.

Pärtel M, Helm A, Reitalu T, Liira J, Zobel M. 2007. Grassland diversity related to the Late Iron Age human population density. Journal of Ecology 95:574-82.

Pärtel M, Mändla R, Zobel M. 1999. Landscape history of a calcareous (alvar) grassland in Hanila, western Estonia, during the last three hundred years. Landscape Ecology 14:187-96.

Pärtel M, Zobel M. 1999. Small-scale plant species richness in calcareous grasslands determined by the species pool, community age and shoot density. Ecography 22:153-9.

Perez-Mendez N, Jordano P, Garcia C, Valido A. 2016. The signatures of Anthropocene defaunation: cascading effects of the seed dispersal collapse. Sci Rep 6:24820.

Peri PL, Lasagno RG. 2010. Biomass, carbon and nutrient storage for dominant grasses of cold temperate steppe grasslands in southern Patagonia, Argentina. Journal of Arid Environments 74:23-34.

Perring MP, De Frenne P, Baeten L, Maes SL, Depauw L, Blondeel H, Carón MM, Verheyen K. 2016. Global environmental change effects on ecosystems: the importance of landuse legacies. Global Change Biology 22:1361-71.

Plue J, Hermy M, Verheyen K, Thuillier P, Saguez R, Decocq G. 2008. Persistent changes in forest vegetation and seed bank 1,600 years after human occupation. Landscape Ecology $23: 673-88$

Porensky LM, Veblen KE. 2015. Generation of Ecosystem Hotspots Using Short-Term Cattle Corrals in an African Savanna. Rangeland Ecology \& Management 68:131-41.

Poschlod P, Baumann A. 2010. The historical dynamics of calcareous grasslands in the central and southern Franconian Jurassic mountains: a comparative pedoanthracological and pollen analytical study. The Holocene 20:13-23.

Poschlod P, Bonn S. 1998. Changing dispersal processes in the central European landscape since the last ice age: an explanation for the actual decrease of plant species richness in different habitats? Acta Botanica Neerlandica 47:27-44.

Poschlod P, WallisDeVries MF. 2002. The historical and socioeconomic perspective of calcareous grasslands-lessons from the distant and recent past. Biological Conservation 104:36176.

Purschke O, Sykes MT, Reitalu T, Poschlod P, Prentice HC. 2012. Linking landscape history and dispersal traits in grassland plant communities. Oecologia 168:773-83.

Rackham AG-O, Grove AT. 2001. The Nature of Mediterranean Europe. Yale: Yale University Press.

Rixon AJ, Zorin M. 1978. Transformations of nitrogen and phosphorus in sheep faeces located in saltbush rangeland and on irrigated pasture. Soil Biology and Biochemistry 10:34754.

Robertson GP, Vitousek PM. 1981. Nitrification potentials in primary and secondary succession. Ecology 62:376-86.

Robin V, Nelle O, Talon B, Poschlod P, Schwartz D, Bal M-C, Allée P, Vernet J-L, Dutoit T. 2018. A comparative review of soil charcoal data: spatiotemporal patterns of origin and longterm dynamics of Western European nutrient-poor grasslands. The Holocene 28:1313-24. 
Römermann C, Dutoit T, Poschlod P, Buisson E. 2005. Influence of former cultivation on the unique Mediterranean steppe of France and consequences for conservation management. Biological Conservation 121:21-33.

Rowarth JS, Gillingham AG, Tillman RW, Syers JK. 1985. Release of phosphorus from sheep faeces on grazed, hill country pastures. New Zealand Journal of Agricultural Research 28:497-504

Russell EWB. 2019. People and the land through time. New Haven: Yale University Press.

Saggar S, Mackay AD, Hedley MJ, Lambert MG, Clark DA. 1990. A nutrient-transfer model to explain the fate of phosphorus and sulphur in a grazed hill-country pasture. Agriculture, Ecosystems \& Environment 30:295-315.

Schnyder H, Locher F, Auerswald K. 2010. Nutrient redistribution by grazing cattle drives patterns of topsoil $\mathrm{N}$ and $\mathrm{P}$ stocks in a low-input pasture ecosystem. Nutrient Cycling in Agroecosystems 88:183-95.

Scott NA, Tate KR, Ford-Robertson J, Giltrap DJ, Smith CT. 1999. Soil carbon storage in plantation forests and pastures: land-use change implications. Tellus B: Chemical and Physical Meteorology 51:326-35.

Selbie DR, Buckthought LE, Shepherd MA. 2015. The challenge of the urine patch for managing nitrogen in grazed pasture dystems. Advances in Agronomy 129:229-92.

Shahack-Gross R. 2011. Herbivorous livestock dung: formation, taphonomy, methods for identification, and archaeological significance. Journal of Archaeological Science 38:205-18.

Shahack-Gross R, Simons A, Ambrose SH. 2008. Identification of pastoral sites using stable nitrogen and carbon isotopes from bulk sediment samples: a case study in modern and archaeological pastoral settlements in Kenya. Journal of Archaeological Science 35:983-90.

Shand CA, Coutts G. 2006. The effects of sheep faeces on soil solution composition. Plant and Soil 285:135-48.
Shi P, Schulin R. 2018. Erosion-induced losses of carbon, nitrogen, phosphorus and heavy metals from agricultural soils of contrasting organic matter management. Science of the Total Environment 618:210-18.

Stiles WA, Rowe EC, Dennis P. 2017. Long-term nitrogen and phosphorus enrichment alters vegetation species composition and reduces carbon storage in upland soil. Science of the Total Environment 593:688-94.

Tiessen H, Stewart JWB, Bettany JR. 1982. Cultivation Effects on the Amounts and Concentration of Carbon, Nitrogen, and Phosphorus in Grassland Soils 1. Agronomy Journal 74:831-5.

Vanwalleghem T, Verheyen K, Hermy M, Poesen J, Deckers J. 2004. Legacies of Roman land-use in the present-day vegetation in Meerdaal Forest (Belgium)? Belgian Journal of Botany 181-7.

Verheyen K, Bossuyt B, Hermy M, Tack G. 1999. The land use history (1278-1990) of a mixed hardwood forest in western Belgium and its relationship with chemical soil characteristics. Journal of Biogeography 26:1115-28.

Verheyen K, Hermy M. 2001. The relative importance of dispersal limitation of vascular plants in secondary forest succession in Muizen Forest, Belgium. Journal of Ecology 89:829-40.

Vinograd A, Zaady E, Kigel J. 2019. Dynamics of soil nutrients in abandoned sheep corrals in semi-arid Mediterranean planted forests under grazing. Journal of Arid Environments 164:3845.

WallisDeVries MF, Poschlod P, Willems JH. 2002. Challenges for the conservation of calcareous grasslands in northwestern Europe: integrating the requirements of flora and fauna. Biological Conservation 104:265-73.

Wells TCE, Sheail J, Ball DF, Ward LK. 1976. Ecological studies on the Porton Ranges: relationships between vegetation, soils and land-use history. The Journal of Ecology 589-626. 